\title{
Construir a cidadania glocal nos confins da terra espinhosa
}

\author{
José Marques de Melo
}

MELO, JM. Cidadania glocal, identidade nordestina: ética da comunicação na era da internet [online]. Campina Grande: EDUEPB; Latus, 2011. 108 p. ISBN 978-85-63984-07-4. Available from

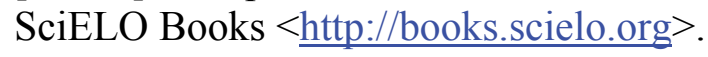

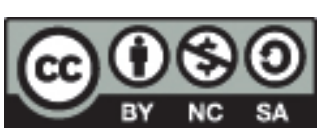

All the contents of this work, except where otherwise noted, is licensed under a Creative Commons Attribution-Non Commercial-ShareAlike 3.0 Unported.

Todo o conteúdo deste trabalho, exceto quando houver ressalva, é publicado sob a licença Creative Commons Atribuição Uso Não Comercial - Partilha nos Mesmos Termos 3.0 Não adaptada.

Todo el contenido de esta obra, excepto donde se indique lo contrario, está bajo licencia de la licencia Creative Commons Reconocimento-NoComercial-CompartirIgual 3.0 Unported. 


\section{Construir a cidadania glocal nos confins da terra espinhosa ${ }^{1}$}

O provincianismo xenófobo e o paroquia-

lismo ufanista costumam inocular a síndrome da efemeridade precoce aos capítulos da nossa micro-História. Por isso, as narrativas do Cotidiano municipal ou do Imaginário local quase sempre permanecem circunscritas às fronteiras das próprias comunidades que as motivaram.

Fugir aos padrões convencionais desse gênero da literatura historiográfica foi o grande desafio dos organizadores e co-autores da coletânea Sertão Glocal, destinada a resgatar a memória da nossa terra. Pensamos num

1 Alocução proferida em Santana do Ipanema (Alagoas), no dia 16 de setembro de 2010, no lançamento do livro Sertão Glocal (Maceió, EDUFAL, 2010). 
livro destinado às novas gerações. Tanto dos santanenses que hoje habitam o território desbravado pelo Padre Francisco Correia, quanto dos brasileiros que se interessam pelo avanço civilizatório no espaço nacional velozmente globalizado.

Comunidade fincada em pleno sertão alagoano, Santana do Ipanema exibe uma identidade mutante, determinada pela sua condição geopolítica transitiva.

A pobreza de recursos hídricos a converteu historicamente em "terra de passagem". Seus habitantes primitivos cultivaram o nomadismo caeté, entrecortado por estâncias perió20 dicas que coincidiam com as cheias do riacho Camoxinga, cuja água potável se diluía na foz, ao desaguar no Ipanema.

Nas estiagens prolongadas, os nativos se deslocavam para os rincões mais irrigados. Transitavam ciclicamente entre as Águas Belas (terra dos fulni-ô) e a Água Branca (refúgio dos "pankararus"). Ou cruzavam os Dois Riachos em busca das minas d água que brotavam no pé da serra, em Palmeira dos Índios (terra dos xucurus). Também corriam léguas, pousando no Olho D'Água das Flores, mas atraídos pelo Pão de Açúcar, banhado pela água doce proveniente da Cachoeira que, séculos depois, seria conhecida pelo nome de Paulo Afonso, seu notável "descobridor". 
Os nossos primeiros colonizadores batizaram o local como Ribeira do Panema, edificada na confluência do rio Ipanema com o riacho Camoxinga. Rio de "água imprestável", o Ipanema corre temporariamente. Seu leito é irrigado pelo caudal impetuoso de água salinizada, quando chove na sua distante cabeceira, em pleno sertão pernambucano.

Não é sem razão que ao chegar àquelas plagas para fundar uma casa de beatas, o Padre Francisco Correia tenha invocado a proteção de Santa Ana, mãe de Maria e avó de Jesus, numa espécie de pacto divino capaz de propiciar dias chuvosos para nutrir o solo fértil, engordar o gado leiteiro e matar a sede dos mestiços que por ali se aventuravam.

Compreende-se, também, porque Graciliano Ramos descreveu Santana como "terra espinhosa", cuja paisagem é dominada por mandacarus e cujos remanescentes populacionais, condenados à barbárie resultante do isolamento, nas frequentes e prolongadas estiagens, eram induzidos a permanecer "fora da lei".

O avanço tecnológico de certo modo removeu os fatores que entravaram nosso progresso. A vida cotidiana da cidade quase nada tem a ver com os tempos dos nossos avôs. A eletrificação sepultou os candeeiros e as lamparinas, o abastecimento d'água aposentou os jumentos e seus tangedores, a mutação da 
economia trouxe maior equilíbrio entre a produção agropecuária e a prestação de serviços típica do setor terciário.

Hoje, torna-se notória a gradativa conversão do espaço santanense em polo educacional.

O processo irrompe em 1938. A fundação do Grupo Escolar arrefece o êxodo rural, retendo temporariamente os jovens dos clãs matutos. Pois as empobrecidas famílias, residentes na roça, sofrendo as agruras do minifúndio, demandam a rua para alfabetizar as novas gerações, assim qualificando o contingente migratório direcionado ao sudeste fabril.

Prossegue em 1950. A criação do Ginásio atrai jovens das redondezas para dominar saberes compatíveis com as oportunidades advindas do funcionamento da rede de serviços (bancos, oficinas, escritórios, repartições públicas) necessárias ao desenvolvimento do capitalismo na região.

Chega ao seu ápice em 2010. A implantação da universidade, principiada em 1995, pela rede estadual de ensino superior, formando zootecnólogos e pedagogos, aprofunda-se com a chegada da universidade federal, instalando o polo de negócios no Campus Sertão da UFAL - Universidade Federal de Alagoas. 
A vocação mercantil de Santana do Ipanema converte-se em fator determinante dessa revolução cultural. Desde os primeiros passos da nossa atividade produtiva, temos uma sociedade atrelada ao mercado internacional. Inserida na "civilização do couro", a nossa vida econômica, lastreada pela agricultura de subsistência, teve como eixo principal a exportação de peles bovinas e caprinas, mais recentemente de laticínios.

Atentas, por dever de ofício, às flutuações do mercado exportador, as nossas elites assimilaram, por tabela, os componentes da cultura nacional e os resíduos da cultura global nela impregnados, forjando uma cultura mestiça em permanente mutação.

Trata-se de ingrediente civilizatório que nos condicionou historicamente, outrora alimentado pelos ciclos migratórios, tendo como agentes os santanenses que robusteceram a diáspora alagoana dentro do território nacional. O avanço das telecomunicações pôs fim ao isolamento sertanejo e agora a disseminação da internet colocou Santana definitivamente na aldeia global.

Projetado como um testemunho dos intelectuais orgânicos da diáspora santanense, o livro Sertão Glocal reaviva o simbolismo diluído pelo tempo e esmaecido pelo espaço. Seus autores são majoritariamente escritores ou 
criadores que preservaram a memória glocalizada às margens do Ipanema, transformando suas lembranças em aluvião capaz de tornar perene o fluxo hídrico do rio que corre no imaginário daqueles que nasceram ou viveram na cidade abençoada pela Senhora Santana.

Foram convocados, para este mutirão telúrico-afetivo, representantes de várias gerações, que podem ser identificadas através de três figuras emblemáticas.

A geração do começo do século comparece por intermédio do nonagenário pediatra social Aguinaldo Nepomuceno Marques, que está celebrando o cinquentenário do seu livro 24 "Fundamentos do Nacionalismo".

Por sua vez, o ícone da geração do meio é o sexagenário José Geraldo Wanderley Marques, ecólogo e poeta, cuja produção literária está eivada do lirismo santanense e da nostalgia sertaneja.

Finalmente, a nova geração aparece por intermédio do argonauta que pilota semanalmente a nave portadora das "Saudações Caetés". Virgílio Wanderley Nepomuceno Agra, apesar de forjado no simbolismo objetivo da engenharia, preservou a verve literária e a subjetividade dos ancestrais batavos, socializando suas impressões do cotidiano via internet. 
O Sertão Glocal emerge assim como espaço geocultural cujas raízes estão fincadas no árido solo calcinado pela falta d’água, mas nutrido pela têmpera dos seus renitentes povoadores, cujas "vidas secas" denotam teimosia, confiança, perseverança. Mesmo tendo que migrar para sobreviver, retornam periodicamente para reciclar as baterias enfraquecidas pela distância. 